\title{
Degradation of $p$-Toluenesulphonic Acid via Sidechain Oxidation, Desulphonation and meta Ring Cleavage in Pseudomonas (Comamonas) testosteroni T-2
}

\author{
By HANS H. LOCHER, THOMAS LEISINGER AND ALASDAIR M. COOK* \\ Microbiology Institute, Swiss Federal Institute of Technology, ETH-Zentrum, CH-8092 Zürich, \\ Switzerland
}

(Received 19 December 1988; revised 10 March 1989; accepted 5 April 1989)

\begin{abstract}
Pseudomonas (Comamonas) testosteroni T-2 completely converted $p$-toluenesulphonic acid (TS) or $p$-sulphobenzoic acid (PSB) to cell material, $\mathrm{CO}_{2}$ and sulphate, with growth yields of about $5 \mathrm{~g}$ protein $(\mathrm{mol} \mathrm{C})^{-1}$. PSB and sulphite were excreted as transient intermediates during growth in TS-salts medium. All reactions of a catabolic pathway involving sidechain oxidation and cleavage of the sulphonate moiety as sulphite were measurable in the soluble portion of cell extracts. Degradation of TS and PSB was inducible and apparently involved at least two regulons. TS was converted to $p$-sulphobenzyl alcohol in a reaction requiring NAD(P)H and $1 \mathrm{~mol} \mathrm{O}_{2}(\mathrm{~mol} \mathrm{TS})^{-1}$. This alcohol was in an equilibrium (in the presence of $\mathrm{NAD}^{+}$) with $p$-sulphobenzaldehyde, which was converted to PSB in an NAD(P)+-dependent reaction. PSB was desulphonated to protocatechuic acid in a reaction requiring $\mathrm{NAD}(\mathrm{P}) \mathrm{H}$ and $1 \mathrm{~mol} \mathrm{O}_{2}(\mathrm{~mol}$ PSB $)^{-1}$. Experiments with ${ }^{18} \mathrm{O}_{2}$ confirmed involvement of a dioxygenase, because both atoms of this molecular oxygen were recovered in protocatechuate. Protocatechuate was converted to 2-hydroxy-4-carboxymuconate semialdehyde by a 4,5-dioxygenase.
\end{abstract}

\section{INTRODUCTION}

Several aliphatic, glyco and aryl sulphonates occur naturally (Laskin \& Lechevalier, 1984), and so they might be expected to be biodegradable. However, some synthetic detergents (Cain, 1981), sulphonated dyestuffs (Meyer, 1981) and their precursors (Bretscher, 1981) are generally poorly degraded. The appearance of these chemicals in rivers (Malle, 1978) indicates a need for a better understanding of their metabolism.

Proof of quantitative degradation of individual aromatic sulphonates has accumulated in recent years (Cain \& Farr, 1968; Brilon et al., 1981 a; Thurnheer et al., 1986; Nörtemann et al., 1986; Zürrer et al., 1987; Wittich et al., 1988; Locher et al., 1989) and desulphonation of aryl sulphonates serving as carbon sources for growth involves liberation of the sulphonate moiety as sulphite (Johnston et al., 1975). There have been very few observations of high rates of desulphonation by cell-free systems (Thurnheer et al., 1986; cf. Heyman \& Molof, 1968; Willetts \& Cain, 1972; Endo et al., 1977; Locher et al., 1989). In consequence, Brilon et al. (1981b) suggested a mechanism of dioxygenolytic desulphonation based on results of experiments with whole cells. Known degradative pathways for aromatic sulphonates with short sidechains seem to involve initial desulphonation, followed by standard pathways for the resultant aromatic ring structures (Cain \& Farr, 1968; Brilon et al., 1981 b; Swisher, 1987). In at least one case, failure to desulphonate an intermediate caused serious growth inhibition (Kulla et al., 1983). $p$-Toluenesulphonate (TS), which is mainly used as a hydrotropic agent in detergent formulations, has served as a model compound in studies of the biodegradation of alkylated benzenesulphonates and was found to be degraded via 4-methylcatechol (Cain \& Farr, 1968; Focht \& Williams, 1970).

Abbreviations: PSB, p-sulphobenzoic acid; SOL, p-sulphobenzyl alcohol; SYD, p-sulphobenzaldehyde; TS, p-toluenesulphonate 
We now present a complete mass balance for the metabolism of TS by Pseudomonas (Comamonas) testosteroni T-2 (Thurnheer et al., 1986), a fast-growing organism that facilitates examination of metabolism in cell-free extracts. TS is first oxidized in three steps to $p$-sulphobenzoate (PSB), and this is then desulphonated by the action of a dioxygenase before meta ring cleavage.

\section{METHODS}

Materials. TS $(99 \%)$ was from Fluka and PSB $(98 \%)$ from Aldrich; each compound was chromatographically pure. Crude $p$-sulphobenzaldehyde (SYD) (Clayton Aniline, Manchester, UK) contained a major peak, a significant impurity (PSB) and traces of several apolar compounds when examined by HPLC; the material in the major peak had a UV-spectrum similar to that of benzaldehyde (Table 1) and material from the peak was confirmed to be SYD by converting it to PSB via the NAD+-dependent action of yeast aldehyde dehydrogenase. Pure SYD in solution was obtained by semi-preparative HPLC and was quantified as PSB after oxidation by aldehyde dehydrogenase. $p$-Sulphobenzyl alcohol (SOL) was prepared from SYD by the NADH-dependent reaction of horse liver alcohol dehydrogenase. Pure SOL in solution was obtained by semi-preparative HPLC and was quantified as SYD after oxidation by aldehyde dehydrogenase. 2-Sulphobenzoic acid and 3-sulphobenzoic acid were supplied by TCI (Tokyo, Japan). The sources of other aryl sulphonates were described by Thurnheer $e t$ al. (1986). 2-Hydroxy-4-carboxymuconate semialdehyde was obtained as the ring-cleavage product from protocatechuate in P. testosteroni NCIB 8893 (Dagley \& Patel, 1957). Horse liver alcohol dehydrogenase (EC 1.1.1.1; Boehringer), yeast aldehyde dehydrogenase (EC 1.2.1.5; Sigma) and cofactors (Boehringer) were from commercial sources. ${ }^{18} \mathrm{O}_{2}$ (isotope enrichment $97 \%$ ) was purchased from CEA-ORIS, Gif-sur-Yvette, France. Diazomethane was prepared from nitrosomethylurea as described by Darbre (1970). All other chemicals were of reagent grade or better.

Apparatus and analyses. Spectrophotometric and optical density measurements (Thurnheer $e$ t al., 1986), and capillary GC (Scholtz et al., 1987) were done with apparatus described previously. Capillary GC-MS was done with a Carlo Erba chromatograph (model 5300) coupled to a Kratos mass spectrometer (model 25RF). HPLC was done with an LKB apparatus fitted with a UV-detector and a diode array detector (Pharmacia). Aromatic compounds were routinely determined by HPLC with reversed-phase columns (Grossenbacher $e$ t al., 1986) and isocratic elution at room temperature. The mobile phase was $100 \mathrm{mM}$-potassium phosphate buffer, $\mathrm{pH} 2 \cdot 2$, with an appropriate amount of methanol $(0$ to $40 \%, \mathrm{v} / \mathrm{v})$; on occasion, the eluent was at $\mathrm{pH} 7$ and the column was cooled in an ice-water slurry. Oxygen consumption was measured in a Clark-type electrode (Oxi 91; WTW, Weilheim, FRG) with a $6 \mathrm{ml}$ chamber which contained $24 \mathrm{mg}$ protein (supernatant fluid from cell extract after centrifugation at $100000 \mathrm{~g}$ for $90 \mathrm{~min}$ ), $3 \mu \mathrm{mol} \mathrm{NADH}, 300 \mu \mathrm{mol} \mathrm{Tris} / \mathrm{HCl}$ buffer, $\mathrm{pH} 7 \cdot 2$, and $0.2 \mu \mathrm{mol}$ substrate, with which the reaction was started. Net oxygen uptake was calculated from total uptake by correction for endogenous respiration. Methyl $O, O^{\prime}$-dimethylprotocatechuate was quantified or its mass spectrum examined after separation on a phenylmethyl silicone capillary GC column (Scholtz et al., 1987); splitless injection and a flow rate of $30 \mathrm{ml}$ $\mathrm{He} \mathrm{min}^{-1}$ were used. Samples were injected at an oven temperature of $140^{\circ} \mathrm{C}$ and a temperature gradient $\left(8^{\circ} \mathrm{C}\right.$ $\mathrm{min}^{-1}$ ) was applied to $210^{\circ} \mathrm{C}$, after which the temperature was raised to $300^{\circ} \mathrm{C}$ at $20^{\circ} \mathrm{C} \mathrm{min}{ }^{-1}$. Sulphite (Grant, 1947; as in the modification of Kondo et al., 1982), sulphate (Schauder et al., 1986; Johnston et al., 1975) and protein from whole cells (Cook \& Hütter, 1981) or in extracts (Bradford, 1976) were measured by routine colorimetric methods. Dissolved organic carbon was measured by standard methods (Greenberg et al., 1981).

Organism, growth medium and quantitative aspects of growth. Pseudomonas testosteroni $\mathrm{T}-2$ was isolated by Thurnheer $e$ t al. (1986) as Pseudomonas sp. strain T-2, whose taxonomic status was refined by chemotaxonomy (G. Auling, personal communication). The growth medium contained $40 \mathrm{~mm}$-potassium phosphate buffer ( $\mathrm{pH} 7 \cdot 2$ ), $20 \mathrm{mM}-\mathrm{NH}_{4} \mathrm{Cl}, 0.25 \mathrm{mM}-\mathrm{MgSO}_{4}$, trace elements (Thurnheer et al., 1986) and a single carbon source (up to $6 \mathrm{mM}$ ); complete medium could be autoclaved $\left(121^{\circ} \mathrm{C}, 20 \mathrm{~min}\right)$ without loss of components or formation of a precipitate. Determination of growth yield [as the regression line of protein formed (mol carbon) ${ }^{-1}$ in carbon-limited batch cultures], growth kinetics, the preparation of large amounts of cells for enzyme assays, and removal and storage of samples from cultures were as described by Thurnheer et al. (1986). P. testosteroni NCIB 8893 was obtained from the NCIB, Aberdeen, UK.

Preparation of cell extracts and enzyme assays. Pellets of harvested, active cells could be frozen and thawed without loss of activity (desulphonation of TS). Bacteria were suspended in $50 \mathrm{mM}$-Tris/ $\mathrm{HCl}$ buffer, $\mathrm{pH} 7 \cdot 2$, disrupted in a French press, and, after centrifugation of disrupted material at low or high speed, the supernatant fluid was used for enzyme assays, with or without desalting, as previously described (Thurnheer et al., 1986). This crude extract lost activity (desulphonation) on freezing and thawing. Enzyme assays were routinely done in $5 \mathrm{ml}$ reaction mixtures, which were shaken in a water bath at $30^{\circ} \mathrm{C}$. The assays contained $250 \mu \mathrm{mol}$ Tris $/ \mathrm{HCl}$ buffer (pH 7.2), $2.5-20 \mathrm{mg}$ protein, $5 \mu \mathrm{mol}$ NADH (unless otherwise stated) and $7.5 \mu \mathrm{mol}$ substrate, with which the reaction was started. Samples were taken at intervals for determinations of substrate disappearance and product formation as detailed by Thurnheer et al. (1986). No substrate disappeared or gave rise to sulphite in the absence of enzyme and no sulphite or interference in HPLC determinations was observed in cell extracts. NADH at 

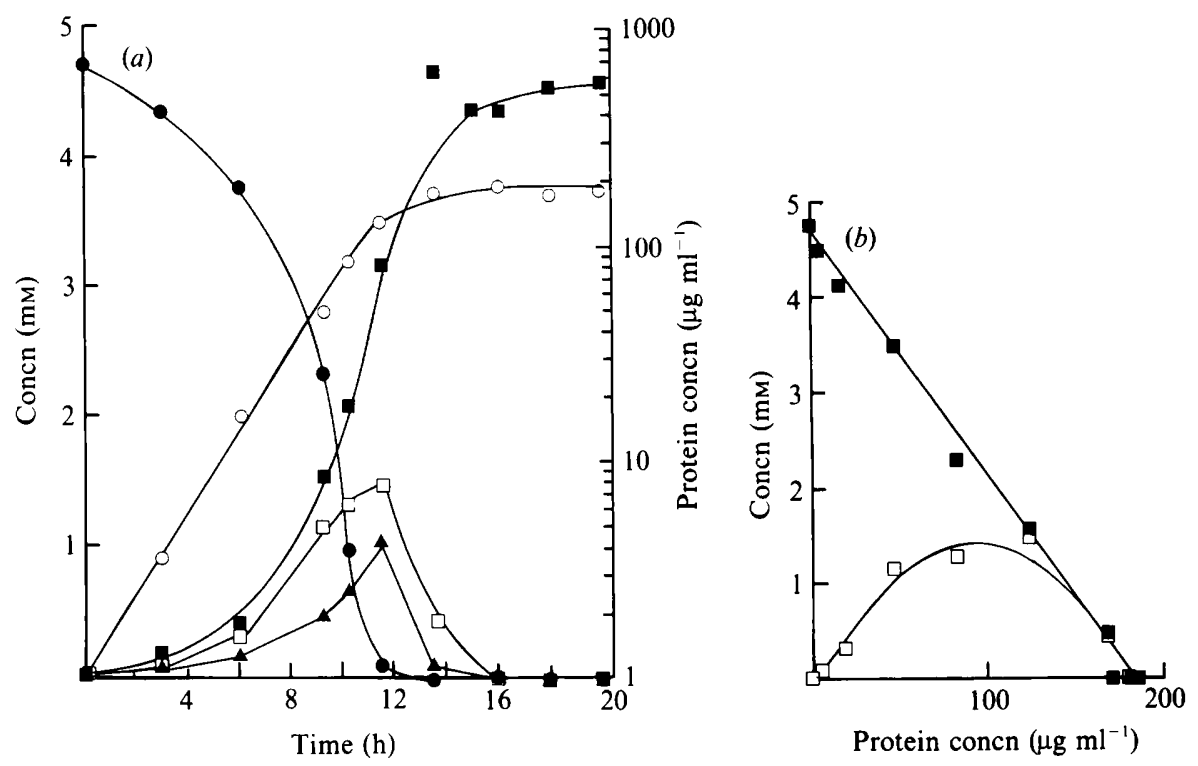

Fig. 1. Growth of $P$. testosteroni T-2 with TS as the sole added carbon and energy source. The organism was pregrown in TS-salts medium at $30^{\circ} \mathrm{C}$ and cells in the exponential phase of growth were used to inoculate fresh medium $(300 \mathrm{ml})$ in a 2-litre Fernbach flask. Samples were taken at intervals for determinations of protein, aromatic compounds and inorganic ions. (a) The growth curve. $0, T S$; $O$, protein; $\square$, PSB; $\square$, sulphate; $\boldsymbol{\Delta}$, sulphite. (b) Differential plot of the growth experiment. The concentration of the excreted PSB or the sum of the concentrations of TS and PSB (i.e. the available carbon source) is plotted as a function of the corresponding protein concentration. $\square,[\mathrm{TS}]+[\mathrm{PSB}] ; \square$, PSB observed in the medium.

concentrations above about $1.0 \mathrm{~mm}$ interfered with the sulphite assay, and standard curves for sulphite were modified appropriately. Kinetic constants were calculated from Lineweaver-Burk plots of data from appropriate reaction mixtures. Experiments under anaerobic conditions were done as previously described (Cook et al., 1984; Thurnheer et al., 1986).

Experiments to follow the incorporation of oxygen into PSB were done in $100 \mathrm{ml}$ serum bottles which were closed with butyl rubber stoppers and which contained defined atmospheres of nitrogen $(80 \%, \mathrm{v} / \mathrm{v})$ and oxygen $\left({ }^{16} \mathrm{O}_{2},{ }^{18} \mathrm{O}_{2}\right.$ or both $; 20 \%$, v/v). Reaction mixtures $(10 \mathrm{ml})$ contained $10 \mathrm{mg}$ protein (desalted cell extract), $20 \mu \mathrm{mol}$ NADH, $10 \mu \mathrm{mol}$ EDTA and $500 \mu \mathrm{mol}$ degassed Tris/ $\mathrm{HCl}$ buffer, $\mathrm{pH} 7 \cdot 2$. Air in the bottles was replaced by three cycles of evacuation and purging with $\mathrm{N}_{2}$. A portion $(20 \mathrm{ml})$ of the gas phase was removed with a gas-tight syringe and replaced with $20 \mathrm{ml}$ of ${ }^{16} \mathrm{O}_{2}$ or ${ }^{18} \mathrm{O}_{2}$, or $10 \mathrm{ml}$ each of ${ }^{18} \mathrm{O}_{2}$ and ${ }^{16} \mathrm{O}_{2}$. The reaction was started by injection of $30 \mu \mathrm{mol}$ PSB $(50 \mu \mathrm{l})$. After $60 \mathrm{~min}$, the reaction was stopped by the addition of $350 \mu \mathrm{l}$ of $70 \%(\mathrm{v} / \mathrm{v})$ perchloric acid. Protein was removed by centrifugation and the supernatant fluid was extracted twice with equal volumes of diethyl ether. The ether fractions were dried over anhydrous $\mathrm{Na}_{2} \mathrm{SO}_{4}$ and concentrated to a volume of $1 \mathrm{ml}$. Methanol $(100 \mu l)$ was added and solutes were methylated with diazomethane (Darbre, 1970). The solvents were removed in vacuo and the residue was dissolved in $200 \mu \mathrm{l}$ of methanol prior to GC-MS analysis.

\section{RESULTS}

\section{Physiology}

$P$. testosteroni T-2 grew in salts medium containing TS, PSB or $p$-hydroxybenzoate with growth yields of $4.6,5.0$ or $5.0 \mathrm{~g}$ protein $(\mathrm{mol} \mathrm{C})^{-1}$. Each of these stable carbon sources disappeared from the medium, negligible amounts ( $<5 \%$ ) of dissolved organic carbon remained and the sulphonate moiety (where present) was recovered in molar yields of $100-110 \%$ as sulphate (Fig. 1a), which was identified by two methods. These data show that strain T-2 converts each of these carbon sources quantitatively to cell material and $\mathrm{CO}_{2}$ (cf. Cook, 1987), that the man-made and natural products are utilized with equal facility, and that the $\mathrm{C}-\mathrm{S}$ bond is cleaved. 
Table 1. Data from the UV-spectra of authentic materials and of metabolic intermediates from the metabolism of TS by P. testosteroni T-2

Spectra were measured in a diode array detector after separation by HPLC in a mobile phase at pH $2 \cdot 2$, except for the semialdehyde, which was measured in a spectrophotometer in samples of crude extract after removal of protein by sequential acidification, centrifugation, and neutralization to $\mathrm{pH} 7$. Values in parentheses represent broad maxima and minima, whose precise wavelength was difficult to measure; (s) indicates a shoulder.

Substance

TS

SOL

Putative SOL

Benzaldehyde

SYD

Putative SYD

PSB

Putative PSB

Protocatechuate

Putative protocatechuate

2-Hydroxy-4-carboxymuconate semialdehyde

Putative 2-hydroxy-4-carboxymuconate semialdehyde
Maxima and minima (nm)

\begin{tabular}{rrrrl} 
Max. & \multicolumn{1}{c}{ Min. } & Max. & Min. & Max. \\
194 & 205 & 220 & & \\
194 & 205 & 220 & $(240)$ & $(260)$ \\
194 & 205 & 220 & $(240)$ & $(260)$ \\
198 & 218 & 248 & & $284(\mathrm{~s})$ \\
197 & 220 & 251 & & $289(\mathrm{~s})$ \\
197 & 220 & 251 & & $289(\mathrm{~s})$ \\
195 & 211 & 234 & $(264)$ & 277 \\
195 & 211 & 233 & $(264)$ & 277 \\
205 & $217(\mathrm{~s}) 235$ & 258 & 279 & 291 \\
205 & $217(\mathrm{~s}) 235$ & 258 & 279 & 291 \\
& & & & 410 \\
& & & & 410
\end{tabular}

Kinetic analysis of the growth of strain T-2 showed that TS supported a specific growth rate $(\mu)$ of $0.37 \mathrm{~h}^{-1}$ (Fig. 1a); PSB and $p$-hydroxybenzoate supported rates of 0.30 and $0.53 \mathrm{~h}^{-1}$, respectively (not shown). A transient organic intermediate, which co-chromatographed with authentic PSB, was excreted during growth in TS-salts medium (Fig. $1 a, b$ ). The identity of the intermediate was confirmed by UV-spectroscopy (Table 1) and by co-chromatography with authentic material under different conditions [as the carboxylate anion (at $\mathrm{pH} 7.0$ ) rather than with the carboxyl group protonated (at $\mathrm{pH} 2 \cdot 2)$ ]. Growth was directly proportional to substrate $([\mathrm{TS}]+[\mathrm{PSB}]$ ) utilization (Fig. $1 b$ ), with a yield similar to that observed in batch cultures, so no other significant organic intermediates were excreted. Maximum rates of degradation of TS and PSB during growth were calculated to be 4.6 and $2.6 \mathrm{mkat}(\mathrm{kg} \text { protein })^{-1}$, respectively. Transient excretion of sulphite during growth (Fig. $1 a$ ) showed that the sulphono moiety was cleaved to yield sulphite, which was then oxidized to sulphate. We thus have complete mass balances for carbon and sulphur, and we postulate degradation by sidechain oxidation followed by desulphonation.

Strain T-2 grew with $p$-toluate (but not toluene), $p$-phthalate, benzyl alcohol, benzaldehyde, benzoate and $p$-hydroxybenzoate as sole sources of carbon and energy for growth.

\section{Biochemistry}

Extracts of cells harvested in the exponential phase of growth in TS-salts medium catalysed rapid degradation of TS (Fig. 2). Cells harvested in the stationary phase led to practically inactive preparations. The activity of extracts was unaltered by the removal of particulate matter by ultracentrifugation, indicating that the enzymes involved are soluble. Extracts from cells grown in succinate-salts medium showed no activity towards sulphonated substrates (Table 2) and extracts of cells grown in benzoate-salts, $p$-hydroxybenzoate-salts or $p$-phthalate-salts medium did not significantly desulphonate PSB (results not shown), indicating the inducible nature of the enzymes. Extracts from PSB-grown cells did not transform TS, so at least two regulons appear to be involved in the degradation of TS to natural products.

Introduction of an hydroxyl moiety into the methyl group of TS. Degradation of TS showed an absolute requirement for molecular oxygen, and $1 \mathrm{~mol} \mathrm{O}_{2}$ (mol TS) ${ }^{-1}$ was required for the conversion of TS to PSB (Table 2). There was a requirement for a cofactor of low molecular mass, whose removal by desalting was compensated for by the addition of NADH or NADPH 


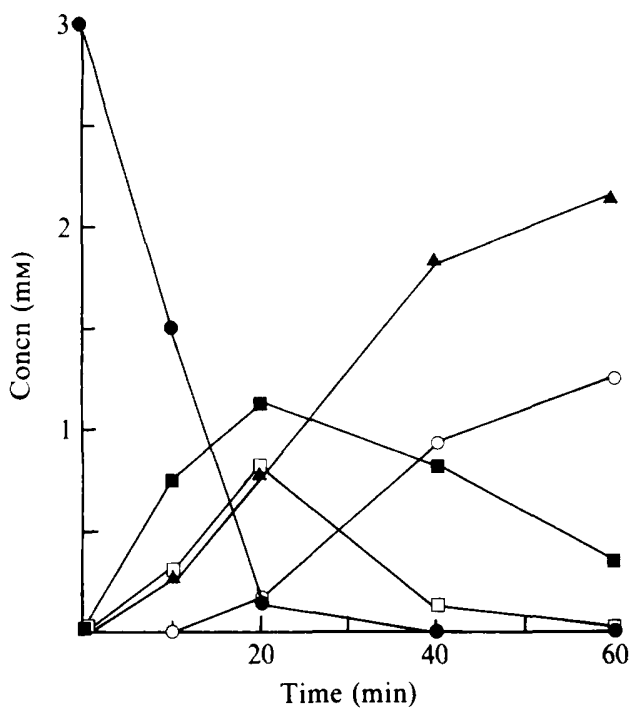

Fig. 2. Degradation of TS in the presence of NADH by extracts of cells of $P$. testosteroni $\mathrm{T}-2$ grown in TS-salts medium. The reaction $\left(30^{\circ} \mathrm{C}\right)$ was started by the addition of crude extract $\left(1 \mathrm{mg} \mathrm{ml}^{-1}\right.$, final concentration) to $50 \mathrm{~mm}-\mathrm{Tris} / \mathrm{HCl}$ (pH 7.2) containing TS and $1 \mathrm{~mm}-\mathrm{NADH}$. Samples were taken at intervals for the determination of organic intermediates and inorganic products. $\mathrm{O}, \mathrm{TS} ; \square, \mathrm{SOL} ; \square$, PSB $; O$, protocatechuate; $\boldsymbol{\Delta}$, sulphite.

Table 2. Specific activities of enzymes in extracts from P. testosteroni T-2 and the oxygen requirement for certain reactions

Specific activities are initial rates of substrate disappearance; oxygen uptake refers to end-point determinations in separate experiments.

\begin{tabular}{|c|c|c|c|c|}
\hline \multirow{2}{*}{$\begin{array}{l}\text { Enzyme } \\
\text { substrate }\end{array}$} & \multirow{2}{*}{$\begin{array}{l}\text { Extracts from } \\
\text { cells grown in } \\
\text { medium containing }\end{array}$} & \multicolumn{2}{|c|}{ 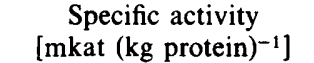 } & \multirow{2}{*}{$\begin{array}{c}\text { Oxygen required } \\
{\left[{\left.\text { mol (mol substrate })^{-1}\right]}^{-1}\right]} \\
\text { TS }\end{array}$} \\
\hline & & . Succinate & TS & \\
\hline TS & & $<0.01$ & 1.0 & $3 \cdot 1$ \\
\hline SOL & & 0.03 & 0.4 & \\
\hline SYD + & & 0.5 & 4.5 & \\
\hline PSB & & $<0.01$ & $0 \cdot 3$ & $2 \cdot 0$ \\
\hline Protocatechuate & & 0.5 & $>2.5$ & $1 \cdot 1$ \\
\hline Toluene & & $\mathrm{NA}$ & $0 \ddagger$ & \\
\hline Benzyl alcohol & & 0.05 & 0.25 & \\
\hline Benzaldehyde $\dagger$ & & $0 \cdot 25$ & 2.5 & \\
\hline 4-Methylcatechol & & $<0.01$ & $<0.01$ & \\
\hline Catechol & & $<0.01$ & $<0.01$ & \\
\hline$p$-Hydroxybenzoate & & 0.04 & $0 \cdot 18$ & \\
\hline
\end{tabular}

NA, Not assayed.

* The standard deviation was $\leqslant 10 \%$ of the mean for three replicates. Reactions relevant only to the degradation of sulphonoaromatics were examined.

$\dagger$ Measured as substrate degradation, i.e. corrected for conversion to the alcohol by the alcohol dehydrogenase.

$\ddagger$ Assayed as oxygen uptake.

to the reaction mixture (Table 3). Activity was observed with $\mathrm{NAD}^{+}$, after a lag phase, but not with $\mathrm{NADP}^{+}$(Table 3). When NADPH was used as a cofactor, SOL was accumulated; its identity was confirmed by co-chromatography with authentic material and by its UV-spectrum (Table 1). The initial reaction with TS thus appears to be catalysed by a monooxygenase. This reaction was activated by $\mathrm{Fe}^{2+}$ and by $\mathrm{Mg}^{2+}$ and was inhibited by ATP (Table 3). The enzyme was saturated at about $0.2 \mathrm{mM}-\mathrm{NADH}$ (not shown), which was required in only catalytic amounts (some $2 \mathrm{~mm}$-substrate converted in the presence of $0.2 \mathrm{mM}-\mathrm{NADH}$ ). 
Table 3. Effect of different compounds on the metabolism of TS and PSB by desalted cell extracts of TS-grown P. testosteroni T-2

The standard assay $(5 \mathrm{ml})$ without NADH was used and the additions indicated in the table were each present at $5 \mu \mathrm{mol}$ per reaction mixture. Disappearance of TS or PSB was followed by HPLC.

\begin{tabular}{|c|c|c|}
\hline \multirow{2}{*}{$\begin{array}{l}\text { Addition } \\
\text { to reaction }\end{array}$} & \multicolumn{2}{|c|}{$\begin{array}{c}\text { Rate of } \\
\text { disappearance } \\
\left.\text { [mkat (kg protein })^{-1}\right] \\
\text { of: }\end{array}$} \\
\hline & TS & PSB \\
\hline None & 0.02 & 0 \\
\hline NADH & 0.83 & 0.33 \\
\hline $\mathrm{NAD}^{+}$ & $0.40^{*}$ & 0.01 \\
\hline NADPH & 0.65 & 0.32 \\
\hline NADP+ & 0.03 & 0 \\
\hline FADH & 0 & 0 \\
\hline $\mathrm{NADH}+\mathbf{M g}^{2+}$ & 0.99 & 0.35 \\
\hline $\mathrm{Mg}^{2+}$ & 0.05 & 0.01 \\
\hline $\mathrm{NADH}+\mathrm{Fe}^{2+}$ & $1 \cdot 20$ & $0 \cdot 70$ \\
\hline $\mathrm{Fe}^{2+}$ & $0 \cdot 1$ & 0.01 \\
\hline NADH + ATP & 0.06 & 0.02 \\
\hline ADP & $\mathbf{0}$ & 0 \\
\hline
\end{tabular}

\footnotetext{
* The reaction started only after a lag phase, in contrast to the immediate reaction in the presence of, e.g.,
} NADH.

Oxidation of SOL to PSB. SOL, accumulated in reaction mixtures containing TS and NADPH, disappeared on the addition of $\mathrm{NAD}^{+}$. We interpret this to indicate the presence of an $\mathrm{NAD}^{+}$-linked SOL dehydrogenase. SYD was a substrate for an NAD(P)+-linked reaction in crude extracts (Table 2), and PSB was observed as an intermediate in this reaction: SOL was also formed when reaction mixtures contained $\mathrm{NAD}^{+}$. We thus observed interconversion of SYD and SOL, and degradation of SYD via PSB.

Both benzyl alcohol and benzaldehyde were degraded by $\mathrm{NAD}^{+}$-coupled enzymes in crude extracts (Table 2) and the aldehyde was partly converted to the alcohol in the presence of NADH. We presume there to be an inducible aromatic alcohol dehydrogenase and an inducible aromatic aldehyde dehydrogenase and that each has broad substrate specificity.

Desulphonation. The desulphonation of PSB in cell-free extracts was dependent on both molecular oxygen (no reaction occurred under anaerobic conditions) and NAD(P)H (Table 3). FADH could not replace NAD(P)H. The addition of $\mathrm{Fe}^{2+}$ led to a doubling of the desulphonation activity (Table 3). Desulphonation of PSB to its product required $1 \mathrm{~mol} \mathrm{O}_{2}$ (mol PSB $)^{-1}$ (Table 2) and led to the release of stoichiometric amounts of sulphite. Up to about 0.7 mol protocatechuate (mol PSB) ${ }^{-1}$ was observed. The identity of the protocatechuate was confirmed by co-chromatography with fully protonated authentic material on reversed-phase HPLC, by its UV-spectrum (Table 1), by co-chromatography with an anionic form of the authentic material ( $\mathrm{pH} \mathrm{7.0)}$ ) and by GC-MS. Methylation of protocatechuate recovered from the oxygenation of PSB in the presence of ${ }^{16} \mathrm{O}_{2}$ yielded three products whose mass spectra identified them as methyl $O, O^{\prime}$-dimethylprotocatechuate (e.g. $\mathbf{M}^{+}=m / z 196,\left[\mathrm{M}-\mathrm{CH}_{3}\right]^{+}=181,[\mathrm{M}-$ $\left.\mathrm{OCH}_{3}\right]^{+}=165$ ) and the two methyl $O$-methylprotocatechuates (data not shown). These data confirmed that protocatechuate is the product from PSB. Protocatechuate formed in the presence of pure ${ }^{18} \mathrm{O}_{2}$ exhibited a mass spectrum 4 mass units higher than described above (not shown), indicating that no oxygen in the phenolic oxygens of protocatechuate derived from water. When both isotopes of molecular oxygen were present, either two atoms of ${ }^{16} \mathrm{O}$ or two atoms of ${ }^{18} \mathrm{O}$ were incorporated (data seen by referees). The desulphonation reaction thus involved a dioxygenase, in agreement with the 1 mol of oxygen consumed by the reaction (Table 2), rather than two monooxygenases, which would have led to the formation of product with each isomer present and which would require $2 \mathrm{~mol}$ oxygen (mol substrate) $)^{-1}$. The accumulation 
Table 4. Range of sulphonated compounds subject to transformation and/or desulphonation by cell-free extracts of $P$. testosteroni T-2 grown in TS-salts medium

Transformation was determined as substrate disappearance. Desulphonation was assayed as release of sulphite. The limit of detection was 0.01 mkat (kg protein $)^{-1}$.

$\begin{array}{lcc} & \begin{array}{c}\text { Transformation } \\ \text { Substrate }\end{array} & \begin{array}{c}\text { Desulphonation } \\ \text { [mkat (kg protein) }\end{array} \\ \text { TS } & 0.90 & 0.32 \\ \text { PSB } & 0.27 & 0.29 \\ \text { 2-Sulphobenzoate } & 0 & 0 \\ \text { 3-Sulphobenzoate } & 0 & 0 \\ \text { Benzenesulphonate } & 0 & 0 \\ \text { 2-Aminobenzenesulphonate } & 0 & 0 \\ \text { 3-Aminobenzenesulphonate } & 0.04 & 0 \\ \text { 4-Aminobenzenesulphonate } & 0.05 & 0 \\ \text { 4-Hydroxybenzenesulphonate } & 0.05 & 0\end{array}$

of protocatechuate was affected by the activity of the ring-cleavage enzyme (see below). The $K_{\mathrm{m}}$ of the desulphonating enzyme for NADH was about $0.3 \mathrm{mM}$. This cofactor was apparently required in stoichiometric amounts.

Only one compound was desulphonated by cell extracts, PSB (and PSB derived from TS) (Table 4). Three sulphonates with meta and para substituents were transformed without desulphonation to unidentified products, which were detected by HPLC. Unsubstituted and ortho-substituted sulphonates did not serve as substrates.

Ring cleavage of protocatechuate. This reaction was dependent on the presence of molecular oxygen [1 mol (mol protocatechuate) ${ }^{-1}$; Table 2] and a divalent cation. $\mathrm{Fe}^{2+}$ was the most effective cation and the addition of 2 mM-EDTA blocked the reaction. The product of ring cleavage was yellow (at pH 7, absorption maximum $410 \mathrm{~nm}$ ) and underwent a reversible blue shift under acidic conditions, corresponding to the published data for 2-hydroxy-4carboxymuconate semialdehyde (Ribbons \& Evans, 1961). The yellow product had the same UV-spectrum as, and coeluted from reversed-phase HPLC with, authentic 2-hydroxy-4carboxymuconate semialdehyde. The organism thus contains a meta ring-cleavage system for protocatechuate.

\section{DISCUSSION}

The degradative pathway for TS in P. testosteroni T-2 (Fig. 3) has been established by demonstrating each reaction and by identifying the intermediates. This pathway differs from the established initial desulphonation of TS, with the release of 4-methylcatechol (Cain \& Farr, 1968; Focht \& Williams, 1970; Thurnheer, 1988), in that several metabolic steps precede desulphonation. Oxidation of a sidechain prior to manipulations on the ring is a common alternative to initial attack on the ring (Fewson, 1981), but previous work on homologues of linear alkyl benzene sulphonate detergents showed desulphonation to precede manipulations of sidechains with fewer than five carbon atoms (Swisher, 1987). One other example of desulphonation of a small organosulphonate subsequent to initial metabolic transformation is known: the deamination of $p$-aminobenzenesulphonate to 4-sulphocatechol in a mixed culture (Feigel \& Knackmuss, 1988). Furthermore, Locher et al. (1989) observed a transient intermediate, which has the UV-spectral properties of 4-sulphocatechol, during the degradation of $p$-hydroxybenzenesulphonate, and this identification has now been confirmed $(\mathrm{H}$. H. Locher, unpublished).

The four enzymic steps demonstrated between TS and protocatechuate are inducible and organized in at least two regulons. There is nothing unusual in this genetic organization (cf. Fewson, 1988). We would anticipate one or more systems to transport these polar sulphonates into the bacterial cell prior to degradation by the soluble enzymes (Fig. 3). No evidence is currently available in $P$. testosteroni T-2, but Thurnheer (1988) has evidence for a stereospecific permeability barrier to sulphonates in Alcaligenes sp. strain O-1. 
<smiles>Cc1ccc(S(=O)(=O)O)cc1</smiles>

(1)

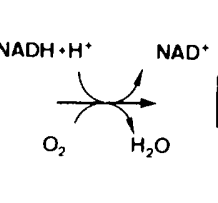

(2)<smiles>O=S(=O)(O)c1ccc(CO)cc1</smiles>

(2)

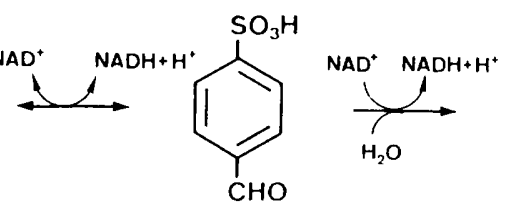

(3)<smiles>O=C(O)c1ccc(S(=O)(=O)O)cc1</smiles>

(4)

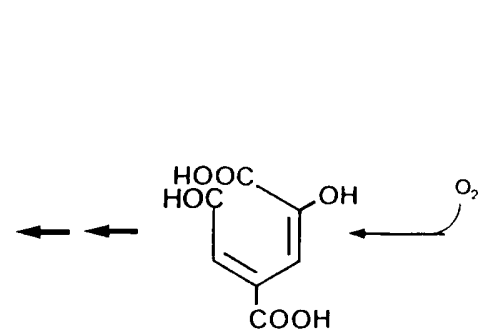

(8)

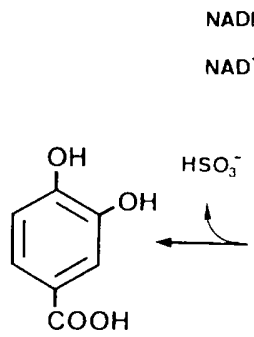

(6)<smiles>CC(C)(C)O</smiles><smiles>C[C@H]1C=C(C(=O)O)C=CC1(O)O</smiles>

(5)

Fig. 3. The degradative pathway of TS in $P$. testosteroni T-2. The numbers represent: (1), p-toluenesulphonate (TS); (2), p-sulphobenzyl alcohol (SOL); (3), p-sulphobenzaldehyde (SYD); (4), $p$-sulphobenzoate (PSB); (5), theoretical intermediate; (6), protocatechuate; (7), 4-carboxy-2-hydroxymuconate semialdehyde; $(8)$, meta-cleavage pathway.

Our evidence for a soluble TS-monooxygenase excludes the introduction of a hydroxyl group from water (cf. Hopper, 1978). Dehydrogenases for aromatic alcoholic sidechains usually display a wide substrate spectrum (MacKintosh \& Fewson, 1988), although several isofunctional enzymes may be synthesized. Dehydrogenases for SOL and SYD are induced during growth of $P$. testosteroni T-2 in TS-salts medium (Table 2), but it is not proven that they are synthesized specifically to degrade sulphonates. We do not know how many isofunctional enzymes are available to the cell.

The data show that desulphonation is concomitant with dioxygenation, but they do not eliminate the possibility that the sulphono-dihydrodiol (Fig. 3) occurs as an intermediate (cf. Brilon et al., 1981 b), that is subject to desulphonation by a dihydrodiol dehydrogenase. We have observed, however, a requirement of $1 \mathrm{~mol}$ NADH (mol PSB oxidized) ${ }^{-1}$, whereas the activity of a dihydrodiol dehydrogenase would regenerate the NADH consumed in the dioxygenation, such that only catalytic amounts of NADH would be required (as with TS monooxygenase). We thus presume the mechanism proposed by Brilon et al. (1981 b), i.e. spontaneous desulphonation of any sulphono-dihydrodiol, to represent the reaction.

The assay of ring-activating dioxygenases (as opposed to, for example, ring-cleavage dioxygenases) in cell-free preparations is still relatively unusual (Irie et al., 1987), and, with the exception of Thurnheer $e$ al. (1986), the few reports of desulphonation in crude extracts describe very low specific activities [1-10 $\mu$ kat (kg protein) ${ }^{-1}$; Heyman \& Molof, 1968; Willetts \& Cain, 1972; Endo et al., 1977; Locher et al., 1989]. Our activity is some two orders of magnitude higher [0.7 mkat PSB (kg protein) ${ }^{-1}$ (Table 2 )], and is $27 \%$ of the activity displayed by growing cells. This is an improvement on our previous work (Thurnheer et al., 1986) and is relatively higher than that observed for many dioxygenases (Gibson et al., 1982). Similarly, the activity of TS monooxygenase (Table 2 ) is $22 \%$ of that required by growing cells [ $4.6 \mathrm{mkat}$ ( $\mathrm{kg}$ protein) ${ }^{-1}$ ]. The high level of the monooxygenase in growing cells, compared with the rate of desulphonation, would explain the excretion of PSB (Fig. 1a).

We are grateful to Dr H. Männli, Versuchsstation schweiz., Brauereien, for obtaining the mass spectra, to Dr T. Egli, EAWAG, for measuring total organic carbon and to Ms B. Capaul, OC, ETH, for the gift of nitrosomethylurea. This investigation was supported by a grant from the Kommission zur Förderung der wissenschaftlichen Forschung (Project 1567). 


\section{REFERENCES}

BRADFORD, M. (1976). A rapid and sensitive method for the quantitation of microgram quantities of protein utilizing the principle of protein-dye binding. Analytical Biochemistry 72, 248-254.

BRETSCHER, H. (1981). Waste disposal in the chemical industry. In Microbial Degradation of Xenobiotics and Recalcitrant Compounds, pp. 65-74. Edited by T. Leisinger, A. M. Cook, R. Hütter, \& J. Nüesch. London: Academic Press.

Brilon, C., BeckmanN, W., Hellwig, M. \& KnaCKMUSS, H.-J. (1981a). Enrichment and isolation of naphthalenesulfonic acid-utilizing pseudomonads. Applied and Environmental Microbiology 42, 39-43.

Brilon, C., BeckmanN, W. \& KNackmuss, H.-J. $(1981 b)$. Catabolism of naphthalenesulfonic acids by Pseudomonas sp. A3 and Pseudomonas sp. C22. Applied and Environmental Microbiology 42, 44-55.

CAIN, R. B. (1981). Microbial degradation of surfactants and 'builder' components. In Microbial Degradation of Xenobiotics and Recalcitrant Compounds, pp. 323-370. Edited by T. Leisinger, A. M. Cook, R. Hütter \& J. Nüesch. London: Academic Press.

CAIN, R. B. \& FARR, D. R. (1968). Metabolism of arylsulphonates by micro-organisms. Biochemical Journal 106, 859-877.

Cook, A. M. (1987). Biodegradation of s-triazine xenobiotics. FEMS Microbiology Reviews 46, 93116.

COOK, A. M. \& HüTTER, R. (1981). s-Triazines as nitrogen sources for bacteria. Journal of Agricultural and Food Chemistry 29, 1135-1143.

Cook, A. M., Grossenbacher, H. \& Hütter, R. (1984). Bacterial degradation of $N$-cyclopropylmelamine. The steps to ring cleavage. Biochemical Journal 222, 315-320.

Dagley, S. \& Patel, M. D. (1957). Oxidation of $p$ cresol and related compounds by a Pseudomonas. Biochemical Journal 66, 227-233.

DARBRE, A. (1970). Esterification. In Handbook of Derivatives for Chromatography, pp. 39-103. Edited by K. Blau \& G. S. King. London: Heyden.

ENDo, K., Kondo, H. \& Ishimoto, M. (1977). Degradation of benzenesulphonate to sulphite in bacterial extract. Journal of Biochemistry 82, 13971402.

Feigel, B. \& KNaCKmuss, H.-J. (1988). Bacterial catabolism of sulfanilic acid via catechol-4-sulfonic acid. FEMS Microbiology Letters 55, 113-118.

Fewson, C. A. (1981). Biodegradation of aromatics with industrial relevance. In Microbial Degradation of Xenobiotics and Recalcitrant Compounds, pp. 141179. Edited by T. Leisinger, A. M. Cook, R. Hütter, \& J. Nüesch. London: Academic Press.

FEWSON, C. A. (1988). Microbial metabolism of mandelate: a microcosm of diversity. FEMS Microbiology Reviews 54, 85-110.

Focht, D. D. \& Williams, F. D. (1970). The degradation of $p$-toluenesulphonate by a Pseudomonas. Canadian Journal of Microbiology 16, 309316.

Gibson, D. T., Yeh, W., Lin, T. \& Subramanian, V. (1982). Toluene dioxygenase: a multicomponent enzyme system from Pseudomonas putida. In Oxygenases and Oxygen Metabolism, pp. 51-61. Edited by M. Nozaki, S. Yamamoto, Y. Ishimura, M. J. Coon,
L. Ernster \& R. W. Estabrook. New York: Academic Press.

Grant, W. M. (1947). Colorimetric determination of sulphur dioxide. Analytical Chemistry 19, 345-346.

Greenberg, A. E., Connors, J. J. \& Jenkins, D. (editors) (1981). Organic carbon (total): combustioninfrared method. In Standard Methods for the Examination of Water and Wastewater, 15th edn, pp. 471-475. Washington, DC: American Public Health Association.

Grossenbacher, H., ThurnheER, T., ZÜRreR, D. \& COOK, A. M. (1986). Determination of sulfonated azo dyestuffs and their bacterial metabolites by high pressure liquid chromatography. Journal of Chromatography 360, 219-223.

Heyman, J. J. \& Molof, A. H. (1968). Biodegradation of linear alkylated sulphonates. Environmental Science and Technology 2, 773-778.

HOPPER, D. J. (1978). Incorporation of $\left[{ }^{18} \mathrm{O}\right]$ water in the formation of $p$-hydroxybenzyl alcohol by the $p$ cresol methylhydroxylase from Pseudomonas putida. Biochemical Journal 175, 345-347.

IrIE, S., DoI, S., Yorifuji, T., TAKagi, M. \& Yano, K. (1987). Nucleotide sequencing of the genes encoding benzene oxidation enzymes of Pseudomonas putida. Journal of Bacteriology 169, 5174-5179.

Johnston, J. B., Murray, K. \& Cain, R. B. (1975). Microbial metabolism of aryl sulphonates. A reassessment of colorimetric methods for the determination of sulphite and their use in measuring desulphonation of aryl and alkylbenzene sulphonates. Antonie van Leeuwenhoek 41, 493-511.

Kondo, H., YaZawa, M., Enami, H. \& Ishimoto, M. (1982). Sulphite production from benzenesulphonate by bacterial enzyme. (In Japanese) Ganryu Aminosan 5, 237-242.

Kulla, H. G., Klausener, U., Meyer, U., Lüdecke, B. \& LEISINGER, T. (1983). Interference of aromatic sulpho groups in the microbial degradation of the azo dyes Orange I and Orange II. Archives of Microbiology 135, 1-7.

LASKIN, A. I. \& Lechevalier, H. A. (editors) (1984). CRC Handbook of Microbiology, 2nd edn, vol. 5, pp. 111-127, 576. Boca Raton: CRC Press.

LOCHER, H. H., THURNHEER, T., LEISINGER, T. \& CoOK, A. M. (1989). 3-Nitrobenzenesulfonic acid, 3aminobenzenesulfonic acid and 4-aminobenzenesulfonic acid as sole carbon sources for bacteria. Applied and Environmental Microbiology 55, 492-494.

Mackintosh, R. W. \& Fewson, C. A. (1988). Benzyl alcohol dehydrogenase and benzaldehyde dehydrogenase II from Acinetobacter calcoaceticus. Biochemical Journal 250, 743-751.

Malle, K. G. (1978). Wie schmutzig ist der Rhein? Chemie in unserer Zeit 12, 111-122.

MEYER, U. (1981). Biodegradation of synthetic organic colorants. In Microbial Degradation of Xenobiotics and Recalcitrant Compounds, pp. 371-385. Edited by T. Leisinger, A. M. Cook, R. Hütter \& J. Nüesch. London: Academic Press.

Nörtemann, B., Baumgarten, J., Rast, H. G. \& KNACKMUSS, H.-J. (1986). Bacterial communities degrading amino- and naphthalene-2-sulfonates. Applied and Environmental Microbiology 52, 11951202. 
Ribbons, D. W. \& Evans, W. C. (1961). Oxidative metabolism of protocatechuic acid by certain soil pseudomonads: a new ring-fission mechanism. Biochemical Journal 83, 482-492.

Schauder, R., Eikmanns, B., Thauer, R. K., WidDEL, F. \& FUCHS, G. (1986). Acetate oxidation to $\mathrm{CO}_{2}$ in anaerobic bacteria via a novel pathway not involving reactions of the citric acid cycle. Archives of Microbiology 145, 162-172.

Scholtz, R., Leisinger, T., SUTER, F. \& COOK, A. M. (1987). Characterization of 1-chlorohexane halidohydrolase, a dehalogenase of wide substrate range from an Arthrobacter sp. Journal of Bacteriology 169, 5016-5021.

SwISHER, R. D. (1987). Surfactant Biodegradation, 2nd edn, pp. 517-645. New York: Marcel Dekker.

THURNHEER, T. (1988). Mikrobieller Abbau von substituierten Benzolsulfonsäuren. $\mathrm{PhD}$ thesis, Swiss Federal Institute of Technology, Zürich.
ThurnheER, T., KöHLER, T., COOK, A. M. \& LEISINGER, T. (1986). Orthanilic acid and analogues as carbon sources for bacteria: growth physiology and enzymic desulphonation. Journal of General Microbiology 132, 1215-1220.

Willetrs, A. J. \& CAIN, R. B. (1972). Microbial metabolism of alkylbenzene-p-sulphonate and dodecylbenzene-p-sulphonate. Biochemical Journal 129, 389-402.

WitTich, R. M., Rast, H. G. \& KNaCKmuss, H.-J. (1988). Degradation of naphthalene-2,6- and naphthalene-1,6-disulfonic acid by a Moraxella sp. Applied and Environmental Microbiology 54, 1842-1847. ZÜRRER, D., COOK, A. M. \& LeISINGER, T. (1987). Microbial desulfonation of substituted naphthalenesulfonic acids and benzenesulfonic acids. Applied and Environmental Microbiology 53, 1459-1463. 